\title{
5. THE BASIC PRINCINPLES OF THE WORKING PROCESS FROM NATURE AND THE ROLE OF COMPOSITION IN CREATING LANDSCAPE IN TERMS OF PLEIN-AIR
}

\author{
Iarîna Savițkaia-Baraghin ${ }^{61}$
}

\begin{abstract}
Principles of possession of the landscape painting, applied by masters of the past, as well as theoretical elaborations of scientists in the field of chromatics, psychology and pedagogy of arts, become important components in improving training methods of artists in plein-air in contemporary conditions. The skills and knowledge gained in the process of pleinair studies form professional skills and improve the properties of painting and composition within the workshop. This studying outlines the stringency of training and development methods of creative individuality, especially in plein-air, where the principal teacher is the nature. The plein-air enriches color perception of the real world, located in the air, and mutual relationship of landscape with architecture and space determines knowledge of the issues of proportionality and subordination in compositions, educates sense of proportion and artistic taste. Improving visual mastery into the natural environment contributes to the formation to painters of the necessity to create outside the workshop, which is a necessary condition for the development of individuality and professional skills of the painter.
\end{abstract}

Key words: plein-air, composition, landscape, painting, perspective

\section{Introduction}

Plein-air (from fr. plein air, literally - open air) represents a painting term that means rendering in picture of the full range of rich color changes caused by the action of sunlight and surrounding atmosphere. Plein-air painting was formed as a result of the painters that work in the open full air (not in the studio), based on the direct study of nature in order to reproduce fully as possible its real image. Russian painter I. Repin wrote: To draw directly from nature - that is the upper school and most truthful. Nature is an inexhaustible source of creative ideas. It is important to learn to see, select, receive a boost from creative visual images, to observe decorative nature qualities - plastic shape, silhouette, lines, rhythm, chromatic connections harmony (Клиндухов, Иогансон, Нестерова, 1993).

Giorgio Vasari notion of landscape is used in the sense of sight as the painting subject. Danielle Bartoli believed that the landscape seen ... through the window's gap or any such opening, in its sole discretion, is shown in the distance like landscape in soft tones (Bartolli, 1836, p. 89). Pierto Fantani and Giuseppe Rigutini define the landscape as an entire of view or part of it, as far as is chosen to be the painting subject (Assunto, 1986, p. 241). According to Assunto, landscape is an element within a complex system that includes space, time and place (Idem, p.158).Nicola Zingarelli, the best known Italian

\footnotetext{
${ }^{61}$ Associate Professor PhD., Academy of Music, Drama and Visual Arts from Chișinau, Republic of Moldavia, email: siarina2002@yahoo.com
} 
philologist during the interwar period in Vocabolariu in lingua Italiana, treats the term landscape as a part of the picture, a stretch of land inhabited and civilized, land with plains, mountains, rivers, trees etc. or as a ... beautiful landscape of the panoramic earth image (Zingarelli, 1941, p.48).

\section{Discussions}

The process of landscape making in art shows that this genre is a cultural and intellectual product's datable and explicable in terms of history. Principles of the landscape painting ownership applied by masters of the part, and theoretical elaborations of scientists in the field of chromatics, psychology and pedagogy of arts are being important components in improving methods of training students in plein-air contemporary conditions. Experience shows that students who are accustomed to work in studio conditions become out in pleinair, looking get lost color relationships in the air environment. As a result, the chromatic palette is quite limited, that is mentioned very specifically by the famous French enlightenment of the XVII century Denis Diderot: those who did not study and feel the effect of light and shadow in fields and woods on rural and urban houses' roods, day and night - shall leave the brush from hand, in particularly, he/she should not put in mind of going to become a landscaper [6, p.57].

The skills and knowledge's obtained during the process of tasks in pleinair studies, form professional skills and improve the properties of painting and composition in the studio. This interdependence of the painting forward particularly acute the problem of studying the training and developing methods of creative individuality, especially in plein-air, when the main teacher is represented by nature. In the plein-air enriches the color perception of the real world, located in the air environment, but the ground and mutual relationship of the landscape with architecture and space forms to the students' knowledge the issues of proportionality and subordination in compositions, educate the proportion's sense and artistic taste.

Painting in plein-air provides to painter the opportunity to understand: human and nature universe that are interconnected through a lot unlimited changing relations. To see their harmony and to reproduce painting is required permanent practice and profound academic knowledge (Маслов \& Пленэр, 1984, p. 22). Plein-air work is characterized by unpredictable for the studies, changing the surrounding state. Under such conditions, professional activity, student independence, the development of his artistic initiative is crucial for the successful implementation of the task studies. The environment activities are substantial way for student's cognitive activity.

For stand-alone study of painting in plein-air is necessary to know the peculiarities of light as an important environmental factor. Reflecting the nature of light, we can explain a number of phenomena observed while working on studying. Light reflected from the surface is subject to changes in the atmospheric environment. In artistic practice this means that each color of the object shall be taking into account the aerial perspective. The analysis of the 
color nature is one of the most complicated moments during the process of learning to plein-air painting. In practice, analysis of chromatic form is considered an important step in the perception of nature and its reflection. The color of objects in plein-air is influenced by both direct sun lighting and diffuse and colored lighting of the sky. In plein-air terms, we must take into account the overall effect of the atmosphere objects are immersed in the open air. Further from the observatory located in space objects are visible occur the more air. Remote plans turn bluish shades. Systematic observation on nature state exercises in paintings sketches and studies permit to develop a professional acumen of chromatic vision. The creating process of chromatic construction conventional study can be divided into two staged:

- Highlighting the chromatic main cold-warm relations in nature;

- Identifying colour's group, tonal relationships that form the main study.

At the final stage of work by nature, we clarified the general, tone and chromatic conditions the following principle form the general to the particular and viceversa, three basic attributes: dominant brightness, chromatic tone and saturation. This training approach of inconstant nature involves the following sequence of relationship determining chromatic reports of study:

- from the general environmental condition of color to the objective color of nature and from it to the conventional color in painting.

A particular role in landscapes is the perspective that serves an important expression of spatial depth. The perspective laws allow rendering our surrounding world, which is three-dimensional, in two-dimensional plane on a sheet of paper or fabric. In the mid XIX century and earlier Ages, painters were based on the experience of their observations on the subject. Schelling, for example, wrote the following about perspective: “... a painting, in which the perspective is respected, we will remember less the fact that what we admire is a creative art than that it is not a creative; but if we turn this principle into a general one, then general there would be any art, but it cannot be generally, illusion, i.e., in general cannot constitute the purpose of art, when identifying reality with visible including up to a reality sensuous" (Беда, 1986, p. 18).

Also we should keep in mind that until the Renaissance painting did not approach, in substance, the effect of shadow-light and linear perspective, and probably not just because this did not reflect aesthetic conceptions of that Age, but also for painter did not know anything about them. It the method for the painting evolution discovers the perspective laws were a breakthrough, has not prevented the development of plastic arts that sometimes try to assert some of contemporary theorists. In the late Renaissance Age and later Ages were created many remarkable works, whose artistic forms that has an indispensable element such as aerial perspective and light-shadow effect (Idem, p.25).

Aerial perspective represents the apparent change of some object characteristic under the influence of atmospheric and space environment. Transparent environment is air. But transparency of air is not always constant. Once of the increasing air layer thickness increases the amount of dust particles, pressure etc. object changes outside because of the enveloping layer size. 
However, along with this we must take into account the external shape, hours of the day, solar lighting and season (Волков, 1985, p. 142). We can deduce the next aerial perspective regularities:

- All close objects are seen meticulously, clearly and the distant ones contrary, generalized uncertain; for rendering space, the contours of the front plane, will be performed more pronounced contrasting and far one more bald.

- In the foreground objects appear bulky, light-shadow contrast is more pronounced, and background plan contrast light-shadow seems weaker expressed objects appear bulky; for rendering the space on foreground the objects should be drawn more bulky, and on the background - flatter.

- On the background plan all objects appear darker, as if covered with a layer of smoky air and it changes their actual brightness and the foreground everything seems natural.

- On the foreground all objects possess a polychromatic palette, but on the background - more monochrome (Беда, 1964).

The aerial perspective laws help to render fair and truthful the space. A remarkable role in creating images is inhabited in space organized by a painter after laws and rules of composition. Acquiring landscape composition means not only a necessary school for students of learning plastic arts, but also a means of spiritual development, education of patriotic feelings. Studying the history of the landscape genre, working methods in different materials (watercolour, oil, acrylic, etc.), working methods on the consecrated landscapers composition broads not only student's horizons, but learns to ask and find solutions to the problems with spiritual and moral content.

The principles and working methods on the landscape are current and important in our times as they are necessary in the acquisition by the students of landscape composition, which is developed centuries ago by the eminent landscape painters. It is considered that the first who used the term composition of an artwork in the context was Leon Battista Alberti (1404-1472), Italian painter and architect, art scholar and theorist of the early Renaissance, which considered that: "the composition is a reasonable basis of painting, due to which constitutes the visible objects in a painting" (Волков, 1977, p. 39). The trend toward art composing is the tendency to perceive as a whole, to look and reproduce spatial and temporal diversity. If we determine such notion as composition, it will be clear that it is not a supplement of the image, decoration, but it is the moment of image basis that penetrates differently in various creations because integrity can be higher or less, can have different character integrity (Волков, 1985, p. 12).

Problems of the compositions, laws, processes, means of expression and harmonization were and remain current for artists, architects, i.e., for all those who make art. Knowing the base of the composition, which influences artistic personality development, forms the basis elementary perception of the artwork. Its role in forming personality is very important. Not only work, but also art creates the man. When art is placed on the background, society does not develop, but degrade (Беда, 1981, p. 4). Painters work on a new masterpiece, 
changing hundreds of times color and shape to achieve a perfect work, finds sometimes in amazement that their range, on which they simply mixing paints, turns out to be exactly the bright abstract fabric emanating beauty without possessing any content whatsoever. Accidental color blend was formed in a composition that was not preventive designed, but was born by itself. So there is an absolutely formal of the elements correlation, in this case - the color, which produces the sensation of ordering. This indicator can be called composition. There are many such indicators, but we will highlight the most substantial absolutely necessary in any organized form. So here we are the main three formal indicators of the composition:

- Integrity;

- Presence of dominance;

- Balance.

If the picture or object is entirely covered with the look as a whole, do not separated into separate independent parts, then we present integrity, a first indicator of the composition. Integrity has not necessarily be treated as a monolithic whole; this feeling is much more complicated - there may be gaps between the elements of the composition, intervals, but mutual attraction of the elements, entering their visual highlights of image or object from the surrounding area. Integrity can be part of the picture composition relative to the frame, can be a spot color that the object or figure does not disperse in patches separated accidental. So, integrity is the indoor unit of the composition (Маслов, 1984, p. 5).

Many painters give priority to unity of chromatic composition, subordinating, the center or task general color, creating integrity in their work. The center can be approached as the most active in the coloristic sense, contrasting with the full range, from the darkest to the brightest. But unity and subordination are expressed not only by the unity of subordination color, but also by the unity of form and texture. A major role in creating the composition, according to all the harmony laws, plays harmonization means. These are: relationships between full and empty, mass balance, rhythm, harmony of shapes and colors, contrast, tension, modulation, unity, symmetry and asymmetry, center of interest, order and disorder, lay out, structure, golden section (Беда, 1981, pp. 52-53).

The second formal indicator of the composition is the dominant. In a correct composition is always a main element. Compositional center can usually be immediately observed; i.e., leading serve all other secondary elements, obscuring, emphasizing or directing the eye to the research of the painting. This is a semantic center of the composition. In no case the concept of the composition center is not only linked to be geometric center of the painting. Center, the focus of the composition, its main element may lie in the front, and the distant plane - it does not matter, the main element is the fact that secondary elements lead the gaze to culmination of image, subjecting each of other (Кузин, 1982, р. 7). 
The third indicator of formal composition is compositional balance. The compositional balance is the harmony basis in the work. This is such state of the composition, when all its elements are in balance with each other. Compositional balance, according to the concept is related to symmetry, but the symmetrical composition contains apriori balance quality, so in this case it cannot be considered. We are interested particularly in composition, where items are placed without a symmetry axis or center, where the entire structure is based on artistic intuition in an absolutely concrete situation. Compositional balance depends on the location of the main composition masses, the organization of compositional center, plastic construction and rhythmic of the composition, disaggregation in its proportion, chromatic, tonal and text ratios of some separate parts, the entirely picture etc. (Непомнящий, 1970).

The composition can be balanced through a desert field or a single point, placed in a certain place of the painting, but what place and color intensity must have this point, that we are in general talking. Particular attention should be paid to balance in dynamic compositions where artistic task consists in particular disestablish destruction of balanced calm. The asymmetrical composition, which tends to exceed the boundaries of the canvas, is always balanced. We can be convinced of this, making a very simple manipulation: it is just to cover part of the picture and the other party of composition will fall apart, it will fall apart, it will become fragmented, unfinished (Кузин, 1982, p. 9).

There is a rule in traditional landscape: sky and landscape should not be equal after their compositional mass. If the artist aims to show immense and infinite stretched, he reserves to the sky the most part of the picture and gives to it all his main attention. If the task consists in rendering the thoroughly landscape, then the boundary between heaven and landscape is usually placed much higher than the optical center of the composition. If the border is placed in the middle, the image breaks out into two parts, which is equally claim to priority - and thus infringed the principle of subordination of the secondary to the main one (Непомнящий, 1970, p. 20). Thus, we can conclude that none of the methods and laws of composition in part will create a harmonious work, because they are all interrelated and balanced. And, if in his searches the artist begins to use more active creating means of more expressive image, the result of such approach should become compositional revaluation of the entire construction of the work. It may need to change the proportions, increase or, conversely, decrease the number of composition elements, to review of tonal and color relationships etc. (Беда, 1981, p. 58).

\section{Conclusions}

History of arts offers us various schemes of building composition. In one of this version, organizing center of the composition is performed with smaller form factors, in another - with the highest form factors. Their choice is confirmed by works in plastic solution author and a possible enforcement of compulsory of viability composition conditions: balance, unity and subordination. We make a conclusion that he problems of composition, its laws, 
processes, means of expression and harmonization had being and remaining current for artists, and the main form for learning the painting in plein-air site is study after nature. And the most obvious means of learning is drawings of the teachers. Viewing, usually, has an action more effective then verbal explanations.

\section{Bibliography}

1. Assunto R. (1986). Peisajul şi estetica (1st vol.). Bucureşti: Meridiane.

2. Bartolli D. (1836). Omul desăvârşit. Torino.

3. Zingarelli N. (1941). Dicţionarul limbii italiene. Florenţa: Zanichelli, 1941.

4. Беда Г. (1986). Живопись. Москва: Просвещение.

5. Беда Г. (1981). Основы изобразительной грамоты: Рисунок. Живопись. Композищия. Москва: Просвещение.

6. Беда Г. (1981). Основы изобразительной грамоты: Рисунок. Живопись. Композищия. Москва: Просвещение.

7. Беда Г. (1964). Тоновые и иветовые отношения в жсивописи. Москва: Советский художник.

8. Беда Г. (1981). Основы изобразительной грамоты: Рисунок. Живопись. Композищия. Москва: Просвещение.

9. Волков Н. (1977). Композиция в живописи. Москва: Искусство.

10. Волков Н. (1985). Цвет в живописи. Москва: Искусство.

11. Волков Н. (1985). Цвет в живописи. Москва: Просвещение.

12. Дидро Д. (1980). Эстетика и литературная критика. Москва: Искусство.

13. Клиндухов Н., Иогансон Б., Нестерова Е. (1993). Школа изобразительного искусства. Вып.4. Москва: Изобразительное искусство. 14. Кузин В. (1982). Психология. Москва: Просвящение.

15. Кузин В. (1982). Психология. Москва: Просвящение.

16. Маслов Н. (1984). Пленэр: практика по изобразительному искусству. Москва: Просвещение.

17. Маслов Н. Я., Пленэр. (1984). Практика по изобразительному искусству. Москва: Просвещение.

18. Непомнящий В. (1970). Перспектива в композиции. Чебоксары.

19. Непомнящий В. (1970). Перспектива в композиции. Чебоксары. 